\title{
PRODUCTIVE POTENTIAL OF THE CHERRY TOMATO GENOTYPE GROUP BEFORE INFECTION BY Alternaria tomatophila ${ }^{1}$
}

\author{
HUGO CESAR RODRIGUES MOREIRA CATÃO ${ }^{2 *}$, NILZA LIMA PEREIRA SALES ${ }^{3}$, JOÃO BATISTA DE CAMPOS \\ MENEZES $^{3}$, FRANCIELE CAIXETA ${ }^{4}$, CÂNDIDO ALVES COSTA $^{3}$
}

\begin{abstract}
Early blight (caused by Alternaria tomatophila) is a major disease of tomato with no resistant cultivars. Thus, it is necessary to identify sources of resistance and productive genotypes for the development of new cultivars. Therefore, this study aimed to evaluate the productive potential of cherry tomato genotypes grown in the summer / fall, the severity of early blight on leaves and the incidence of disease in fruits. The treatments consisted of Carolina tomato genotypes, Cereja Vermelho, CH 152 and CLN1561A. The experimental design consisted of randomized blocks with six replications, and the experimental plot had 16 plants. The following characteristics were evaluated: area under the disease progress curve (AUDPC), average number of microinjuries on the fruits (MF), average number of fruits per bunch (NFC), average number of bunches per plant (NCP), average number of fruits per plant (NFP), average yield, number of fruits with incidence of early blight per plant (NFI) and the severity of early blight in leaves (\%). The cherry tomato genotype $\mathrm{CH} 152$ showed tolerance to early blight with a smaller area under the disease progress curve, lower severity and fruits with incidence of A. tomatophila were not observed in this genotype. The CH152 had the highest number of fruits per bunch, greater number of bunches per plant, higher number of fruits per plant and higher productivity. This line has great potential of being integrated into breeding programs.
\end{abstract}

Keywords: Solanum lycopersicum var. cerasiforme. Early blight. Climate conditions. Severity.

\section{POTENCIAL PRODUTIVO DE GENÓTIPOS DE TOMATEIRO DO GRUPO CEREJA DIANTE À INFECÇÃO POR Alternaria tomatophila}

\begin{abstract}
RESUMO - A pinta preta (Alternaria tomatophila) é uma das principais doenças do tomateiro não havendo cultivares resistentes à doença. Com isso, é necessário identificar fontes de resistência e genótipos produtivos na perspectiva de desenvolvimento de novas cultivares. Logo, objetivou com esse estudo avaliar o potencial produtivo de genótipos de tomateiro cereja cultivados no verão/outono, a severidade da pinta preta nas folhas e a incidência da doença nos frutos. Os tratamentos consistiram dos genótipos de tomateiro Carolina, Cereja Vermelho, CH 152 e CLN1561A. O delineamento experimental foi de blocos ao acaso com seis repetições, sendo a parcela experimental constituída por 16 plantas. Foram avaliadas as seguintes características: área abaixo da curva de progresso da doença (AACPD), número médio de microferimentos nos frutos (MF), número médio de frutos por cacho (NFC), número médio de cachos por planta (NCP), número médio de frutos por planta (NFP), produtividade média, número de frutos com incidência de pinta preta por planta (NFI) e a severidade da pinta preta nas folhas (\%). O genótipo de tomateiro cereja $\mathrm{CH} 152$ apresentou tolerância à pinta preta com menor área abaixo da curva de progresso da doença, menor severidade e também não foram observados frutos com incidência de A. tomatophila nesse genótipo. O CH152 apresentou o maior número de frutos por cacho, maior número de cachos por planta, maior número de frutos por planta e maior produtividade. Esta linhagem tem grande potencial para ser integrada em programas de melhoramento genético.
\end{abstract}

Palavras-chave: Solanum lycopersicum var. cerasiforme. Pinta preta. Condições climáticas. Severidade.

\footnotetext{
*Corresponding author

${ }^{1}$ Received for publication in $10 / 28 / 2014$; accepted in 09/08/2016

Paper extracted from the masters dissertation of the first author.

${ }^{2}$ Departament of agriculture, Faculdades Integradas de Ourinhos, Ourinhos, SP, Brazil; hugocatao@yahoo.com.br.

${ }^{3}$ Institute of Agricultural Sciences, Universidade Federal de Minas Gerais, Montes Claros, MG, Brazil; nsales ufmg@hotmail.com, jjbcmenezes@gmail.com, candido-costa@ica.ufmg.br.

${ }^{4}$ Global Center for Technology Creation, General Mills Brasil Alimentos Ltda, Cambará, PR, Brazil; francielecaixeta@yahoo.com.br.
} 


\section{INTRODUCTION}

The growing demand of the consumer market for mini tomatoes (Solanum lycopersicum var. cerasiforme), has greatly aroused the interest of farmers. The introduction of this new tomato group to the market, resulted in its widespread distribution. Also, it created new demands for research on the development of cultivars with high productivity, disease resistance and adaptation to Brazilian conditions (ROCHA et al., 2009).

Among the fungal diseases that affect tomato, early blight is one of the most important and can infect plants anywhere and at any age, provided favorable conditions are found. Reports in the literature have indicated that the severity of the disease is influenced by climatic conditions during the cultivation of tomato plant (SALUSTIANO et al., 2006).

Although the etiology of the disease has been traditionally attributed to the fungus Alternaria solani Sorauer (ROTEM, 1994), in 2000 a new species was described, Alternaria tomatophila Simmons, is commonly associated with the black spot lesions on tomato plants (SIMMONS, 2000; LOURENÇO et al., 2009). In Brazil, it was demonstrated that the fungus $A$. tomatophilia is the etiologic agent of the disease (RODRIGUES et al., 2010). The destructive potential of the disease, associated with cultivars and hybrids at low resistance levels, indicate the fact that the use of fungicides is a major effective management measure used by growers (CATÃO et al., 2013). However, when chemical control isolation is used for disease management, the results are not always effective and long lasting (ZAMBOLIM et al., 2007).

In management programs, to improve and rationalize the use of chemicals, the start and the range of chemicals applied is determined by monitoring environmental conditions, the phenological stage of the culture and mainly by the cultivar resistance level (TOFOLI; DOMINGUES, 2005). Given this perspective, materials were selected that have resistance to certain diseases, such as black spot, so as to increase productivity (PAULA; OLIVEIRA, 2003; GRIGOLLI et al., 2011). Laurindo et al. (2015) reported that BGH-2143 access, BGH-2235, BGH-2270, BGH-2118, belonging to $S$. lycopersicum species are potential sources of resistance to early blight. Thus, the identification of genotypes that have these characteristics becomes very important, as support for the development of tomato breeding programs in tropical and subtropical regions.

However, environmental conditions may affect the expression of resistance genes. Hence, the genotype $\mathrm{x}$ environment interaction has been a major challenge for breeders, because it is possible that the best genotype in one environment is not in another (SQUILASSI, 2003). It becomes extremely important to evaluate the productive potential and resistance levels in function genotypes of climate conditions in certain producing regions and on pathogenic infection, to establish management strategies and also provide subsidies for breeding programs.

In this context, the aim of this study was to evaluate the productivity of cherry tomato genotypes grown in the summer / fall, the severity of early blight on the leaves and the incidence of disease in fruit.

\section{MATERIAL AND METHODS}

The trial was conducted at the Institute of Agricultural Sciences, Federal University of Minas Gerais (ICA / UFMG), from February to June 2010 under field conditions. The climate of the northern region of Minas Gerais, according to Köppen climate classification is Aw - tropical savanna climate with dry winter and rainy summer, also classified as semi-arid.

The treatments consisted of Carolina tomato genotypes, Cereja Vermelho, $\mathrm{CH} 152$ and CLN1561A, the first two commercial cultivars and other lines tolerant to heat were transferred by The World Vegetable Center (AVRCD-Taiwan / China). The experimental design consisted of randomized blocks with six replications, and the experimental plot had 16 plants.

The soil of the experimental area was classified as Cambisol without tomato cultivation history and the results of chemical and physical analyses showed the following characteristics: water $\mathrm{pH}=6.8 ; \mathrm{P}$ Mehlich $\left(\mathrm{mg} \mathrm{kg}^{-1}\right)=55.2$; remaining $\mathrm{P} \quad\left(\mathrm{mg} \mathrm{L} \mathrm{L}^{-1}\right)=29.0 ; \mathrm{K}\left(\mathrm{mg} \mathrm{kg} \mathrm{kg}^{-1}\right)=126$; $\mathrm{Ca}\left(\mathrm{cmolc} \mathrm{dm}^{-3}\right)=7.00 ; \mathrm{Mg}\left(\right.$ cmolc $\left.\mathrm{dm}^{-3}\right)=2.40$; $\mathrm{Al}\left(\mathrm{cmolc} \mathrm{dm}^{-3}\right)=0.00 ; \mathrm{H}+\mathrm{Al}\left(\mathrm{cmolc} \mathrm{dm}^{-3}\right)=1.42$; $\mathrm{SB}\left(\right.$ cmolc $\left.\mathrm{dm}^{-3}\right)=9.72 ; \mathrm{m}(\%)=0$; $\mathrm{T}\left(\right.$ cmolc $\left.\mathrm{dm}^{-3}\right)=11.15 ; \mathrm{V}(\%)=87$; mat. org. $\left(\right.$ Dag kg $\left.^{-1}\right)=4.41$; coarse sand $\left(\mathrm{kg} \mathrm{dag}^{-1}\right)=9.10$; fine sand $($ dag kg-1 $)=40.90 ;$ Silt $\left(\right.$ dag $\left.\mathrm{kg}^{-1}\right)=26.00$; clay $\left(\right.$ dag kg $\left.{ }^{-1}\right)=24.00$.

The seedlings were grown in polystyrene trays containing commercial substrates (pine bark, binders, vermiculite and mineral supplements NPK + micronutrients). At 30 days after sowing, the seedlings were transplanted to the experimental area, spaced $1 \mathrm{~m}$ between rows and $0.5 \mathrm{~m}$ between plants and tutored with narrow ribbon to a height of $1.8 \mathrm{~m}$.

Fertilization was carried out according to the chemical analysis of soil and crop needs at each stage of development. For this purpose, we used the planting $180 \mathrm{~kg} \mathrm{~N} / \mathrm{ha}, 574 \mathrm{~kg} /$ ha of $\mathrm{P}_{2} \mathrm{O}_{5}, 600 \mathrm{~kg} /$ ha $\mathrm{K}_{2} \mathrm{O}$, cover $357 \mathrm{~kg} \mathrm{~N} /$ ha and $297 \mathrm{~kg} /$ ha $\mathrm{K}_{2} \mathrm{O}$ subdivided into three applications. The cultivation and management of the plants were carried out as recommended by the culture, except for the application of fungicides. Irrigation was performed 
by dripping and the calculated volume of water as the water requirement of the crop, was determined by estimating evapotranspiration by tank Class.

During the experimental period, data were collected on temperature $\left({ }^{\circ} \mathrm{C}\right)$, relative humidity $(\%)$ and rainfall $(\mathrm{mm})$ in Meteorology District 5 that was

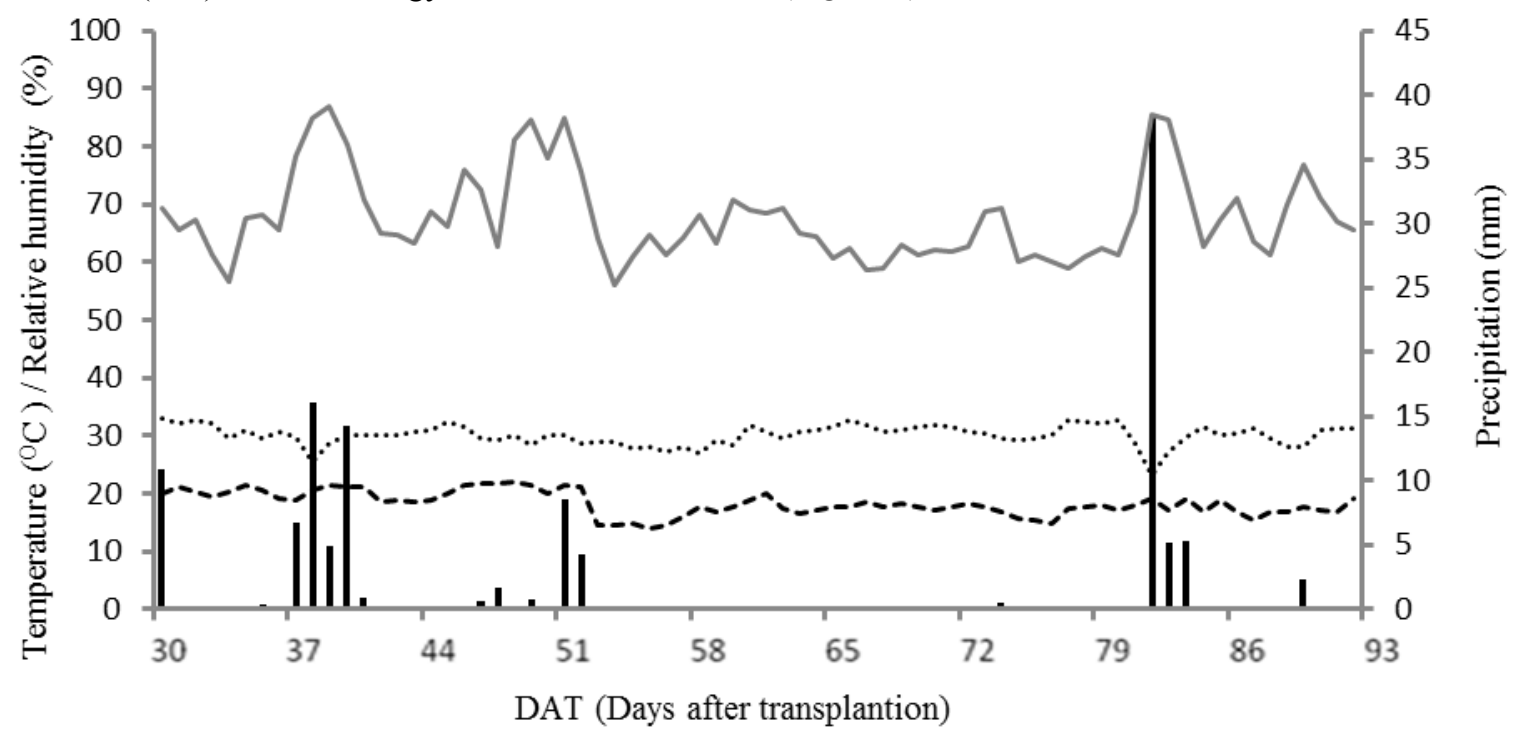

Rainfall Maximum temperature

Minimum temperature

$200 \mathrm{~m}$ away from the experimental area. Subsequently, these data were grouped into weekly averages. These data were compared with disease progress curves for the same time interval, in order to check the influence of climatic conditions (Figure 1).

Figure 1. Meteorological measurements of temperature $\left({ }^{\circ} \mathrm{C}\right)$, relative humidity $(\%)$ and precipitation $(\mathrm{mm})$ obtained in the Montes Claros region in the period from 13/03/2010 to 06/06/2010 (Montes Claros, 2010). Source: National Institute of Meteorology / Weather INMET- 5th District.

Isolates of $A$. tomatophila were obtained from lesions characteristic of early blight, on tomato fruits produced in the region where the test was conducted. From monospores culture (SILVA et al., 2009), pure isolates were obtained from Petri dishes containing $\mathrm{V} 8, \mathrm{CaCO}_{3}$, and agar medium. The plates were incubated for ten days in the dark at $25^{\circ} \mathrm{C}$ to promote mycelial growth. Thereafter, for sporulation, the plates were incubated at a temperature of $18^{\circ} \mathrm{C}$ for $72 \mathrm{~h}$ in the absence of light. After this period, $10 \mathrm{~mL}$ of sterile distilled water was added to each plate, and the conidial suspension was prepared with the aid of a sterile brush (SALUSTIANO et al., 2005).

The conidial suspension was calibrated at a concentration of $3 \times 10^{4}$ conidia / $\mathrm{mL}$ of distilled water with the help of a Neubauer chamber. At 27 days after transplanting the seedlings (DAT), the plants were inoculated via atomization of the inoculum suspension to the point of runoff, using a hand sprayer.

After inoculation, four leaves of the lower, middle and upper third were randomly selected and subsequently marked with wool to make the assessment of severity always the same for leaflets in all evaluations. Weekly, from the onset of symptoms, the severity of early blight was assessed, and the average severity of an average estimate of each plant disease within each plot was determined. The severity, defined as the percentage of leaf area covered by symptoms of the disease was assessed using a diagrammatic scale (BOFF et al., 1991).

The disease progress curve over time for each genotype was constructed from the average values of severity of each plot. The average severity values of each plot were also used to calculate the variable area under the disease progress curve (AUDPC), using the trapezoidal integration proposed by Shaner and Finney (1977).

The fruit harvest began at 120 days after transplantation being performed every five days, and in total eight harvests were obtained. The following characteristics were evaluated: average number of fruits per bunch (NFC), average number of bunches per plant (NCP), average number of fruits per plant (NFP), average productivity (PROD) $\left(\mathrm{t} \mathrm{ha}^{-1}\right)$, number of fruits with incidence of early blight per plant (NFI) and average number of microinjuries on the fruits (MF). For microinjuries evaluation, a sample of 40 fruits was collected from each plot and with the aid of a stereoscopic microscope (40x) were recorded in each result as the number of microinjuries on the fruit of integration with the peduncle, a site of pathogen infection.

Data were subjected to analysis of variance for each characteristic assessed and the effects were evaluated by $\mathrm{F}$ test at $1 \%$ probability. The mean 
when qualitative were compared by the Scott-Knott test at $1 \%$ probability, using SISVAR 5.0 software (FERREIRA, 2011). The averages were plotted using a quantitative scatter plot (severity versus time) to obtain a progress curve blight.

\section{RESULTS AND DISCUSSION}

The cherry tomato genotypes evaluated showed variation in productivity, severity on leaves and incidence of $A$. tomatophila on the fruits (Table 1).

Table 1. Area under the disease progress curve (AUDPC), the average number of microinjuries on the fruits (MF), number of fruits per bunch (NFC), number of grapes per plant (NCP), fruit number per plant (NFP), average productivity (PROD) $\left(\mathrm{t} \mathrm{ha}{ }^{-1}\right)$ and number of fruits with incidence of black spot (NFI) caused by A. tomatophila in cherry tomato genotypes.

\begin{tabular}{lclccccr}
\hline Genotypes & AACPD & MF & NFC & NCP & NFP & PROD & NFI \\
Carolina & $1065 \mathrm{a}$ & $2.60 \mathrm{~b}$ & $7.47 \mathrm{~b}$ & $7.29 \mathrm{c}$ & $54.62 \mathrm{c}$ & $21.41 \mathrm{~b}$ & $12.75 \mathrm{~b}$ \\
Cereja Vermelho & $1145 \mathrm{a}$ & $2.95 \mathrm{a}$ & $10.33 \mathrm{a}$ & $10.58 \mathrm{~b}$ & $109.40 \mathrm{~b}$ & $19.65 \mathrm{~b}$ & $12.71 \mathrm{~b}$ \\
CH 152 & $439 \mathrm{~b}$ & $1.64 \mathrm{c}$ & $12.78 \mathrm{a}$ & $22.48 \mathrm{a}$ & $287.31 \mathrm{a}$ & $30.54 \mathrm{a}$ & $0.00 \mathrm{c}$ \\
CLN1561A & $1221 \mathrm{a}$ & $3.04 \mathrm{a}$ & $6.23 \mathrm{~b}$ & $11.40 \mathrm{~b}$ & $70.87 \mathrm{~b}$ & $22.08 \mathrm{~b}$ & $27.88 \mathrm{a}$ \\
\hline F test values & 41.97 & 21.02 & 15.34 & 12.57 & 26.03 & 25.74 & 21.89 \\
\hline CV $(\%)$ & 13.98 & 12.37 & 11.69 & 6.26 & 12.90 & 7.05 & 6.89 \\
\hline
\end{tabular}

*Means followed by the same letter in the column do not differ by the Scott-Knott test at $1 \%$ probability.

The Carolina genotypes, Cereja Vermelho and CLN1561A showed the highest percentage of severity and area under the disease progress curve (AUDPC) above, 1065, 1145, 1221, respectively, statistically similar and being more susceptible to early blight (Table 1 and Figure 2). Other than that, the $\mathrm{CH} 152$ genotype had the lowest severity (\%) AUDPC and therefore a greater tolerance to $A$. Tomatophila, under the experimental conditions (Table 1 and Figure 2). The format of the disease progress curve provides important information about the dynamics of the disease (AZEVEDO et al., 2012). Thus, this criterion can also be used for selection of the best genotypes (FIORINI et al., 2010). In this situation, it is regarded as the best genotype with less diseased leaf area in the last days of evaluation and priority to selection genotypes whose diseased leaf area is smaller in the initial evaluation periods, which can provide control methods of greater efficiency in the initial period of disease progress and reduce the risk of damage to the crop (LAURINDO et al., 2015).

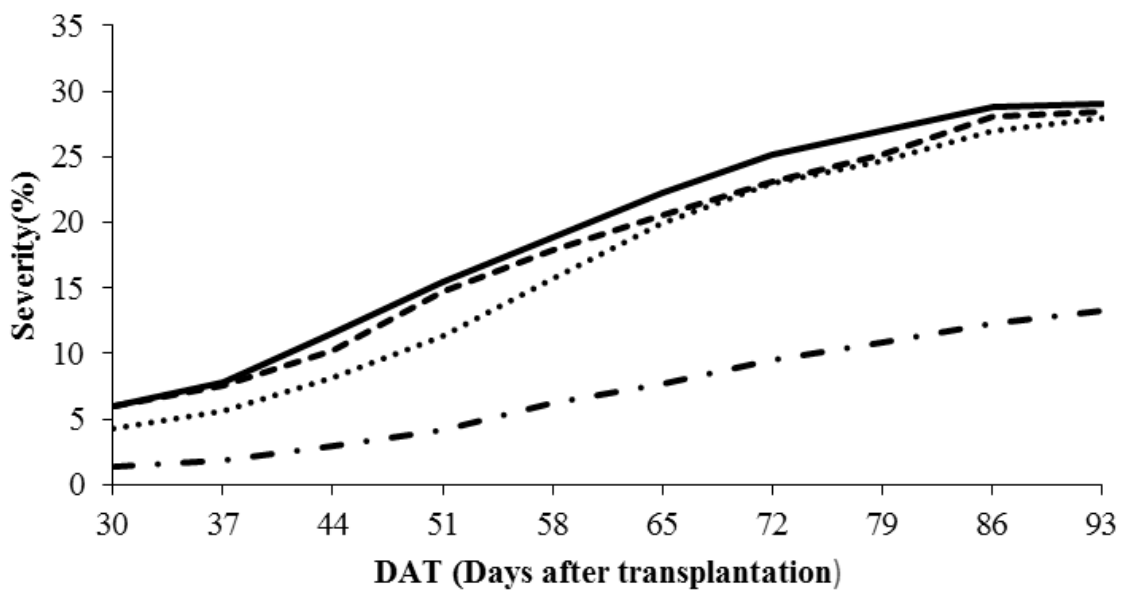

...... Carolina - - Cereja Vermelho - - CH $152-$ CLN 1561-A

Figure 2. Severity (\%) of A. tomatophila versus time (days after transplanting - DAT) in different genotypes of cherry tomato (Montes Claros, 2010).

Paula and Oliveira (2003) reported that the Ohio 4013 genotypes CNPH 738 and Hybrid F1 (Hawaii $7998 \times$ Monense) showed resistance to $A$. solani, especially the Ohio 4013 genotype with AUDPC value of 208.44. Considering the above standard, it can be said that the $\mathrm{CH} 152$ genotype has the potential for genetic resistance to disease. It is worth mentioning that currently there are no varieties with complete resistance to disease. And in this case, with the potential for resistance genotypes, there is need to study and identify genes that influence the strength and transfer them to commercial cultivars through breeding programs.

In this study, it was found that the $\mathrm{CH} 152$ genotype showed the potential for resistance to disease caused by $A$. tomatophila under the growing conditions of cultivation of the North mining semiarid region. However, it is already known that this genotype showed tolerance to the fungus Fusarium oxysporum f. sp. lycopersici race 1 
according to information of the World Vegetable Center. Another important feature of this line is the heat tolerance which may contribute to increasing the tomato cultivation period and becoming incorporated into other operating regions (SILVA et al., 2011).

The severities of cherry tomato genotypes ranged initially from $1 \%$ of diseased leaf area in the $\mathrm{CH} 152$ genotype, to $6 \%$ in other genotypes. At the end of the crop cycle, CH152 showed 13\% of diseased leaf area while the other genotypes showed approximately $30 \%$ (Figure 2). According to Balbi-Peña, Schwan-Estrada and Stangarlin (2014), resistant genotypes have a lower frequency of injuries due to the formation of fewer appressoria on the leaf surface. Thus, assessments of the productive potential of plant genotypes in real infection disease conditions in the field, as in this study, contribute to the selection of cultivars with potential for breeding programs.

The disease severity was lower than $10 \%$ up to 51 DAT (Figure 2). Salustiano et al. (2006) also reported that the initial severity was low $(5 \%)$ and remained at levels below $10 \%$ up to $54 \mathrm{DAT}$, under natural conditions of infection in genotypes Santa Clara and Débora Plus, produced in the region of Viçosa. The same authors also reported that at the beginning of the experiment there was favorable temperature $\left(25\right.$ to $\left.30^{\circ} \mathrm{C}\right)$, leaf wetness was associated most of the time with relative humidity (between 76 and 89\%) and the frequency of rain was higher at the beginning of the assay, favoring disease development. In this study, similar weather conditions were observed (Figure 1).

The prevailing temperatures were around $20-32^{\circ} \mathrm{C}$ during the crop cycle, contributing to the development of the disease. Other studies have confirmed that temperatures in the range $25-32^{\circ} \mathrm{C}$, favor the development of black spots on tomato and epidemic disease (BALBI-PEÑA et al., 2006; SALUSTIANO et al., 2006). The relative humidity ranged from 60 to $90 \%$ during the test which may have promoted the presence of free water on the leaf surface, a fundamental factor for germination, infection and sporulation. Researchers demonstrated that $A$. solani occurs in the infection process in a $14-26^{\circ} \mathrm{C}$ temperature range, with a relative humidity around $100 \%$ during the first $24 \mathrm{~h}$, establishing conditions for the development of the epidemic (ROTEM, 1994; PAUL et al., 2004; BALBI-PEÑA et al., 2006; SALUSTIANO et al., 2006). Such conditions are evident from the 51 DAT indicating a significant increase in disease severity genotypes (Figure 2). Salustiano et al. (2006) stated that the short duration of leaf wetness period reduction in relation to the epidemic and attenuation, consequently attenuate the severity of early blight. There were also showers of low intensity rainfall up to $40 \mathrm{~mm}$ and fairly distributed over the conduct of the experiment (Figure 1). After the first periods of rainfall favored the increase in relative humidity $(90 \%)$ under mild temperatures, it coincided with the phase in which the severity of the disease had significantly progressed (Figure 2).

At 37 DAT and up to 72 DAT, due to rain, high humidity and lower temperatures, the disease found favorable conditions for further development and there was increase in severity and the epidemiological process. The increase in humidity due to the rainy season facilitated the development of early blight, this may be related to the available water on the leaf surface which may have promoted the dispersal and germination of spores (ROTEM, 1994; CHAERANI; VOORRIPS, 2006). These climatic conditions, as mentioned, are favorable to the development of the disease and may occur in several secondary cycles throughout the cycle, leading to the emergence of epidemics. Other reports on climate conditions in the progress of black spots on tomato indicate that severe epidemics occur frequently under marked conditions of temperature higher than $25^{\circ} \mathrm{C}$, combined with high humidity (ROTEM, 1994).

In fruits, black spot lesions are depressed and located in the cup region with crushed aspects and concentric rings, and the infection of the pathogen can be direct through the epidermis or by wounds (MIZUBUTI; BROMMONSCHENKEL, 1996). The CH 152 genotype showed no fruit with symptoms of black spot. This is one of the possible reasons, for the low number of micro-injuries in the cup region. Contrary to this, the CLN11561A recorded the highest number of fruits with symptoms of early blight as a result of the occurrence of micro injuries, having a direct impact on productivity (Table 1). According to Silva et al. (2011), the CLN1561A lineage has high productivity $\left(27.13 \mathrm{t} \mathrm{ha}^{-1}\right)$, but the incidence of early blight on fruit caused depreciation of their appearance and as a result, caused direct losses in productivity (TOFOLI; DOMINGUES, 2005; WAMSER et al., 2008). The increase in susceptibility to early blight is usually associated with fabrics which have reached maturity, or plants flowering period, fruiting (PEREIRA et al., 2013). During these phases, there is an increased demand for sugar and nutrients for fruit formation rather than foliage, which favors the infectious process for exporting bodies (PEREIRA et al., 2013).

High capacity characteristics should also be maintained in materials that have potential for disease resistance. According to the data presented in Table 1, it can be verified that the $\mathrm{CH} 152$ genotype had the highest number of fruits per bunch (not different from Cereja Vermelho), the largest number of bunches per plant, increased number of fruits per plant and increased productivity $\left(\mathrm{t} \mathrm{ha}^{-1}\right)$. These data corroborate with those reported by Silva et al. (2011) and Menezes et al. (2012) who found that strains of the $\mathrm{CH}$ group had high yield potential. Guilherme et al. (2014) also studying the productivity of these 
mini tomatoes in spacing function found that $\mathrm{CH} 152$ stood out from the other genotypes to present higher productivity. Once again, this study showed the productive potential of the $\mathrm{CH} 152$ genotype, in addition to the less severe black spot, this genotype has the potential of being integrated into breeding programs.

\section{CONCLUSION}

The cherry tomato genotype $\mathrm{CH} 152$ showed higher productivity and less severity of blight in relation to other genotypes, and also did not show symptoms of the disease in the fruit under climatic conditions favorable to the development of the pathogen.

\section{ACKNOWLEDGEMENT}

The authors express their gratitude to the Higher Education Personnel Improvement Coordination - CAPES for granting the first author scholarship.

\section{REFERENCES}

AZEVEDO, C. F. et al. Classificação multivariada de curvas de progresso da requeima do tomateiro entre acessos do Banco de Germaplasma de Hortaliças da UFV. Ciência Rural, Santa Maria, v. 42, n. 3, p. 414-417, 2012.

BALBI-PEÑA, M. I. et al. Controle de Alternaria solani em tomateiro por extratos de Curcuma longa e curcumina - II. Avaliação in vivo. Fitopatologia Brasileira, Brasília, v. 31, n. 4, p. 401-404, 2006.

BALBI-PEÑA, M. I.; SCHWAN-ESTRADA, K. R. F.; STANGARLIN, J. R. Oxidative burst and the activity of defense-related enzymes in compatible and incompatible tomato-Alternaria solani interactions. Semina: Ciências Agrárias, Londrina, v. 35, n. 5, p. 2399-2414, 2014.

BOFF, P. L. et al. Escalas para avaliação de severidade da mancha-de-estenfílio (Stemphylium solani) e da pinta preta (Alternaria solani) em tomateiro. Fitopatologia Brasileira, Brasília, v. 16, n. 1, p. $280-283,1991$

CATÃO, H. C. R. M. et al. Fungicides and alternative products in the mycelial growth and germination control of Alternaria tomatophila. Idesia, Arica, v. 31, n. 3, p. 21-28, 2013.

CHAERANI, R.; VOORRIPS, R. E. Tomato early blight (Alternaria solani): the pathogen, genetics, and breeding for resistance. Journal of General Plant Pathology, Tottori, v. 72, n. 6, p. 335-347, 2006.

FERREIRA, D. F. Sisvar: a computer statistical analysis system. Ciência e Agrotecnologia, Lavras, v. 35, n. 6, p. 1039-1042, 2011.

FIORINI, C. V. A. et al. Agrupamento de curvas de progresso de requeima em tomateiro originado de cruzamento interespecífico. Pesquisa Agropecuária Brasileira, Brasília, v. 45, n. 10, p. 1095-1101, 2010 .

GRIGOLLI, J. F. J. et al. Characterization of tomato accessions for resistance to early blight. Crop Breeding and Applied Biotechnology, Viçosa, v. 11, n. 2, p. 174-180, 2011

GUILHERME, D. O. et al. Comparison between cherry tomato in the organic system of cultivation under different spacing. Academia Journal of Agricultural Research, London, v. 2, n. 1, p. 23-29, 2014.

LAURINDO, B. S. et al. Seleção de acessos de tomateiro resistentes à pinta preta pela análise de agrupamento das curvas de progresso da doença. Pesquisa Agropecuária Brasileira, Brasília, v. 50, n. 2, p. 106-114, 2015.

LOURENÇO, V. J. et al. Molecular diversity and evolutionary processes of Alternaria solani in Brazil inferred using genealogical and coalescent approaches. Phytopathology, Saint Paul, v. 99, n. 6, p. 765-774, 2009.

MENEZES, J. B. C. et al. Fruit production and classification of four cherry tomato genotypes under an organic cropping system. Idesia, Arica, v. 30, n. 3, p. 29-35, 2012.

MIZUBUTI, E. S. G.; BROMMONSHENKEL, S. H. Doenças causadas por fungos em tomateiro. Informe Agropecuário, Belo Horizonte, v. 18, $\mathrm{n}$. 184, p. 7-14. 1996

PAUL, P. A. et al. Epidemiologia comparativa da pinta-preta do tomateiro sob quatro regimes de pulverização. Fitopatologia Brasileira, Brasília, v. 29 , n. 5, p. $475-479,2004$

PAULA, R. S.; OLIVEIRA, W. F. Resistência de tomateiro (Lycopersicon esculentum) ao patógeno Alternaria solani. Pesquisa Agropecuária Tropical, Goiânia, v. 33, n. 2, p. 89-85, 2003.

PEREIRA, R. B. et al. Manejo da pinta preta: uma ameaça às lavouras de tomateiro a céu aberto. 1. ed. Brasília: Embrapa Hortaliças, 2013. 5 p. 
(Comunicado técnico 95).

ROCHA, M. C. et al. Descritores quantitativos na determinação da divergência genética entre 358 acessos de tomateiro do grupo cereja. Ciência Rural, Santa Maria, v. 39, n. 3, p. 664-670, 2009.

RODRIGUES, T. T. M. S. et al. First report of Alternaria tomatophila and A. grandis causing early blight on tomato and potato in Brazil. New disease Reports, London, v. 22, n. 28, p. 28, 2010.

ROTEM, J. The genus alternaria: biology, epidemiology, and pathogenicity. Saint Paul: APS, 1994. 326 p.

SALUSTIANO, M. E. et al. O manejo da pinta-preta do tomateiro em épocas de temperaturas baixas. Summa Phytopathologica, Botucatu, v. 32, n. 4, p. 353-359, 2006.

SALUSTIANO, M. E. et al. Patogenicidade de Alternaria helianthi (Hansf.) e Alternaria zinniae (Pape) ao girassol a partir de sementes, Revista Brasileira de Sementes, Londrina, v. 27, n. 1, p. 138-143, 2005.

SHANER, G.; FINNEY, R. E. The effect of nitrogen fertilization on the expression of slow-mildewing resistance in know wheat. Phytopathology, Saint Paul, v. 70, n. 1, p. 1183-1186, 1977.

SILVA, A. C. et al. Avaliação de linhagens de tomate cereja tolerantes ao calor sob sistema orgânico de produção. Revista Caatinga, Mossoró, v. 24, n. 3, p. 33-40, 2011.

SILVA, A. C. et al. Efeito in vitro de compostos de plantas sobre o fungo Colletotrichum gloeosporioides penz. isolado do maracujazeiro. Ciência e Agrotecnologia, Lavras, v. 33, Sup., p. 1853-1860, 2009.

SIMMONS, E. G. Alternaria themes and variations (244-286) species on Solanaceae. Mycotaxon, Ithaca, v. 75, n. 1, p. 1-15, 2000.

SQUILASSI, M. G. Interação de genótipos com ambientes. Embrapa Tabuleiros Costeiros. 2003, 47 p. Disponível em: $<$ http//www.cpatc.embrapa.br.>. Acesso em: 02. dez. 2016

TOFOLI, J. G.; DOMINGUES, R. J. Controle da pinta preta do tomateiro com o uso de acibenzolar-s-metil isolado, em mistura com fungicidas e em programas de aplicação. Arquivos do Instituto Biológico, São Paulo, v. 72, n. 4, p. 481-487, 2005.

WAMSER, A. F. et al. Influência do sistema de condução do tomateiro sobre a incidência de doenças e insetos-praga. Horticultura Brasileira, Brasília, v. 26, n. 2, p. 180-185, 2008.

ZAMBOLIM, L. et al. Manejo da resistência de fungos a fungicidas. Universidade Federal de Viçosa, Viçosa. 2007. 168 p. 